\title{
当教室における喉頭癌の統計的観察
}

\author{
佐藤 洋子・大谷稂・大槻 好正 \\ 村上正文・安斎 友博 $\cdot$ 大内仁
}

\section{A Retrospective Evaluation of 151 Cases of Laryngeal Cancer}

\author{
Yohko Sato, Iwao Ohtani, Kohsei Ohtsuki, \\ Masafumi Murakami, Tomohiro Anzai and Jin Ouchi \\ (Fukushima Medical College)
}

From January 1968 to December 1982, 151 patients with laryngeal carcinoma were treated in our department. Their cases were reviewed retrospectively in December 1984. In 79 cases the cancer was glottic, in 63 it was supraglottic, and in 9 it was subglottic.

According to the UICG TNMsystem (1978), 33 cancers were stage I $(21.9 \%)$, $38(25.2 \%)$ stage II, $59(39 \%)$ stage III and $21(13.9 \%)$ stage IV. The 5-year survival rate was $70.5 \%$ (stage I $82.4 \%$, II $78.9 \%$, III $56.3 \%$, IV $62.5 \%$ ) for the glottic type, $54.3 \%$ (stage I $66.7 \%$, II $66.7 \%$, III $53.8 \%$, IV $37.5 \%$ ) for the supraglottic type and $50 \%$ for the subglottic type.

\section{緒言}

頭頸部悪性腫瘍のうちで, 喉頭癌は上顎癌とと屯に, 最も頻度の多いむのであり, 当教室開講以 来, 昭和32年から昭和 59 年までに取り扱った頭頸部悪性腫瘍のうち，上顎癌35\%に次いで31\%を占 めている，喉頭癌は悪性腫瘍のうちでも，比較的予後のよい腫瘍とされているが，その治療の時期を 失すれば，依然として不幸な転帰をとるてと屯稀ではない，また，その治療法の選択に際しては， 喉頭の機能保存が, 治療側, 患者側にとっても, 大きな問題となる.

われわれは，最近14年間に扱った喉頭癌患者の治療方法および治療成績について，統計的観察を 行い，今後の治療成績の一層の向上を計ることを目的として， $2 ， 3$ の検討を加えたので報告する.

\section{臨 床 的 観 察}

昭和 43 年 1 月より昭和 57 年 12 月までに，当教 室で一次治療を行った喉頭癌症例 151 例を対象 とし, 予後の分析は炤和 59 年 12 月現在で行っ た。

年秢は39歳から85歳までにわたり，60歳台が 最屯多く, 次いで 50 歳台, 70 歳台の順で平均
62.9歳であった。性別は男性 146 例，女性 5 例 (3.3\%) であった（図 1)。病理組織診断は, 全例扁平上皮癌であった。

部位別では, 声阴癌が79例 (52.3\%) で最も 多く，次いで声門上癌63例 (41.7\%) で，声門 下癌は 9 例（5.9\%）と少なかった。1978年の 


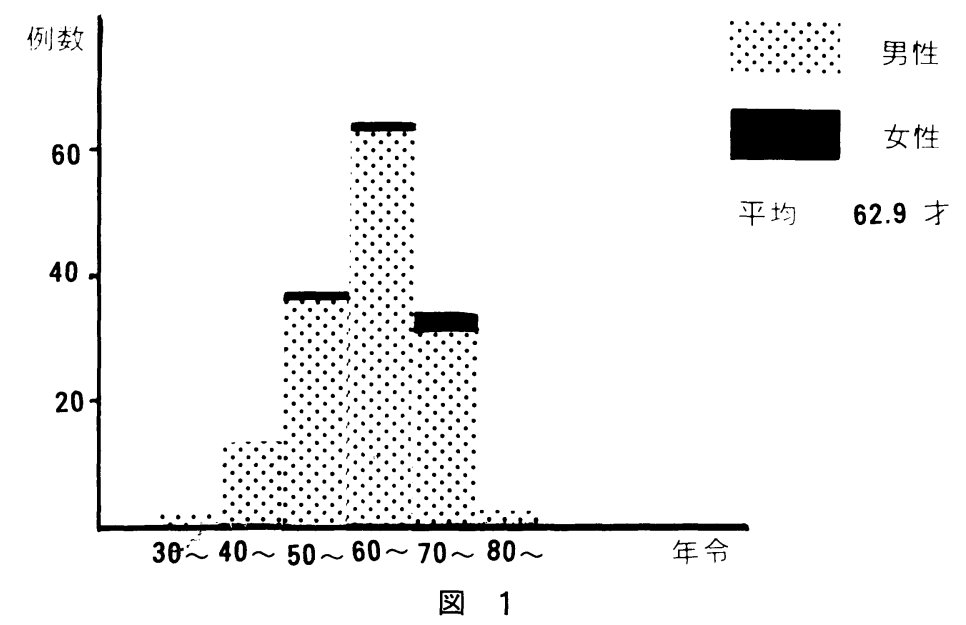

表 1 喉頭癌症例の内訳

\begin{tabular}{|c|c|c|c|c|c|}
\hline $\mathrm{N}$ & 0 & 1 & 2 & 3 & 計 \\
\hline 1 & 23 & 1 & 2 & 0 & 26 \\
\hline 2 & 24 & 2 & 5 & 0 & 31 \\
\hline 3 & 15 & 3 & 1 & 2 & 21 \\
\hline 4 & 1 & 0 & 0 & 0 & 1 \\
\hline 計 & 63 & 6 & 8 & 2 & 79 \\
\hline
\end{tabular}

\begin{tabular}{|c|c|c|c|c|c|}
\hline $\mathrm{T}^{\mathrm{N}}$ & 0 & 1 & 2 & 3 & 計 \\
\hline 1 & 1 & 0 & 0 & 0 & 1 \\
\hline 2 & 5 & 1 & 1 & 0 & 7 \\
\hline 3 & 1 & 0 & 0 & 0 & 1 \\
\hline 4 & 0 & 0 & 0 & 0 & 0 \\
\hline 計 & 7 & 1 & 1 & 0 & 9 \\
\hline
\end{tabular}

声門上癌

\begin{tabular}{c|r|r|r|r|r}
\hline $\mathrm{N}$ & 0 & 1 & 2 & 3 & 計 \\
\hline 1 & 9 & 5 & 0 & 0 & 14 \\
2 & 9 & 2 & 4 & 1 & 16 \\
3 & 22 & 7 & 1 & 3 & 33 \\
4 & 0 & 0 & 0 & 0 & 0 \\
\hline 計 & 40 & 14 & 5 & 4 & 63
\end{tabular}

UICC の分類に基づき, 喉頭癌症例の内訳を表 1 亿示した。喉頭癌全体の Stage 分類は, Stage I (21.9\%), II 38例 (25.2\%), III59例 (39\%), IV21 例（13.9\%）であった。初診時 の頸部リンパ節転移の有無は, $\mathrm{N}_{0}$ が 101 例 (66.9\%)，転移を認めた例は 50 例 $(33.1 \%)$ で, その内訳は $\mathrm{N}_{1} 21$ 例, $\mathrm{N}_{2}$ 14例, $\mathrm{N}_{3} 6$ 例で あった。

\section{治療成績および予後}

喉頭癌症例 151 例のうち, 5 年以上経過し追跡 できた症例は 109 例あり, 全例の 5 年確定生存 率は $62.6 \%$ であった。部位別の 5 年確定生存率 は声門癌が70.5\%で最屯良く, 次いで声門上癌 が54.3\%, 声門下癌が50\%の順であった(表 2). 以下, 治療方法と予後, 部位別病期別予後, 頸
部リンパ節転移例の転州についてのべる。

1. 治療方法および予後

堠頭癌全体の部位別治療内谷および治療法別 5 年碓定生:存率，部位别 5 年破定生存率表表 2 に示した。治療法は初问入院時の内容により分 類した。喉頭癌 151 例忡初回治療として喉頭全 
表 2 喉頭癌の部位別治療内容および治療法別, 部位別 5 年確定生存率

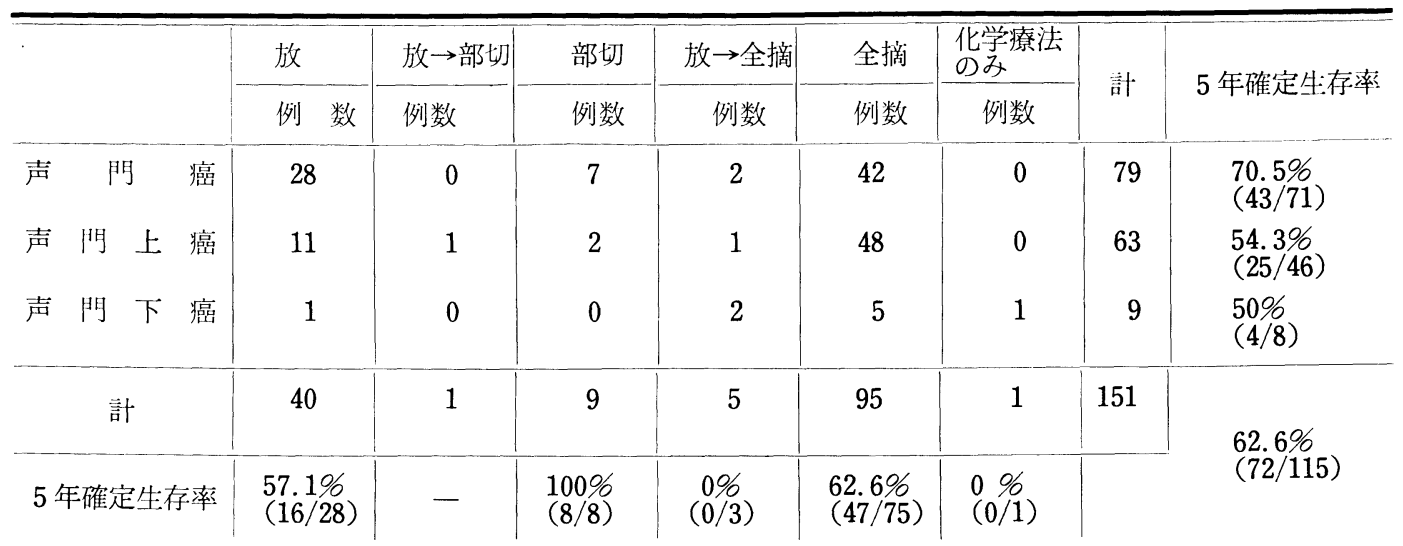

放：放射線療法, 部切: 喉頭部分切除術, 全摘 : 㑨頭全摘出術.

表 3 声門癌の治療法別予後

\begin{tabular}{l|c|c|c|c|c|c|c}
\hline 治 療 法 & 症 例 数 & 局所再発 & 頸部再発 & 腫 瘍 死 & 他 因 死 & 不 明 & 5 年確定生存率 \\
\hline 放 & 28 & 2 & 1 & 3 & 3 & 1 & $72.2 \%(13 / 18)$ \\
部切 & 7 & 1 & 1 & 0 & 0 & 0 & $100 \%(6 / 6)$ \\
放 $\rightarrow$ 全摘 & 2 & 0 & 0 & 1 & 0 & 0 & $0 \%(0 / 1)$ \\
全掉 & 42 & 3 & 5 & 10 & 2 & 4 & $66.6 \%(24 / 36)$
\end{tabular}

表 4 声門上癌の治療法別予後

\begin{tabular}{l|c|c|c|c|c|c|c}
\hline 治 療 法 & 症 例 数 & 局所再発 & 頸部再発 & 腫 瘍 死 & 他 因 死 & 不 明 & 5 年確定生存率 \\
\hline 放 & 11 & 0 & 3 & 7 & 0 & 0 & $33.3 \%(3 / 9)$ \\
放 $\rightarrow$ 部切 & 1 & 0 & 0 & 0 & 1 & 0 & - \\
部切 & 2 & 0 & 0 & 0 & 0 & 0 & $100 \%(2 / 2)$ \\
放 $\rightarrow$ 全摘 & 1 & 0 & 1 & 1 & 0 & 0 & $0 \%(0 / 1)$ \\
全摘 & 48 & 0 & 13 & 9 & 4 & 6 & $58.8 \%(20 / 34)$
\end{tabular}

摘出術（以下全摘）を行ったものが最も多く 95例（62.9\%）を占め，放射線治療法が 40 例

（26.4\%）であった。喉頭部分切除術（以下部 切）は 9 例 $(5.9 \%)$ と少なかった。放射線治 療後に全摘を行ったのが 5 例 $(3.3 \%)$ あっ た。治療法別 5 年確定生存率は, 放射線療法が $57.1 \%$ ，全摘が $62.6 \%$ で，全摘の方がやや良か った。部切は 8 例のみであったが全例生存して いた。

部位別に，治療法および予後をみると，声門 癌では表 3 の如く, 全摘が42例（53.2\%）と最 屯多く, 次いで放射線療法 28 例 $(35.4 \%)$, 部 切は 7 例 $(8.9 \%)$ であった。また 2 例（2.5
\%) に放射線照射後に全摘が行われた。局所再 発は，放射線も全摘も約 $7 \%$ と同じ位であった が, 腫瘍死の占める割合は, 全摘が放射線療法 のほぼ 2 倍であった。声門癌の治療法別 5 年確 定生存率は，放射線が $72.2 \%$ ，全摘の $66.6 \%$ より良好であった。部切は 6 例のみであるが, いずれも生存していた。声門上癌では，表 4 の 邚く全摘が48例（76\%）之压倒的に多く，放射 線療法は11例 (17.5\%) で, 部切は 2 例のみで あった。いずれの方法であ局所再発はみられな かった。放射線療法での腫瘍死は 11 例中 7 例 （63.6\%）乙高かった。 5 年確定生存率は全摘 $58.5 \%$ ，放射線療法 $33 \%$ と不良であったが，部 
表 5 声門癌の原発巣治療および予後

\begin{tabular}{|c|c|c|c|c|c|c|c|c|c|}
\hline Stage & $\begin{array}{l}\text { 症例 } \\
\text { 数 }\end{array}$ & 治 療 法 & 症 例 数 & 局所再発 & 頸部再発 & 腫 瘍死 & 他 因死 & 不 & 5 年確定生:存率 \\
\hline \multirow{3}{*}{ I } & \multirow{3}{*}{23} & 放 & 18 & 2 & 0 & 1 & 1 & 1 & \multirow{3}{*}{$\begin{array}{l}82.4 \% \\
(14 / 17)\end{array}$} \\
\hline & & 部切 & 4 & 0 & 0 & 0 & 0 & 0 & \\
\hline & & 全摘 & 1 & 0 & 0 & 0 & 0 & 0 & \\
\hline \multirow{3}{*}{ II } & \multirow{3}{*}{24} & 放 & 7 & 0 & 0 & 2 & 0 & 0 & \multirow{3}{*}{$\begin{array}{l}78.9 \% \\
(15 / 19)\end{array}$} \\
\hline & & 部比 & 2 & 0 & 0 & 0 & 0 & 0 & \\
\hline & & 全摘 & 15 & 1 & 3 & 4 & 1 & 1 & \\
\hline \multirow{3}{*}{ III } & \multirow{3}{*}{21} & 放 & 3 & 0 & 1 & 0 & 2 & 0 & \multirow{3}{*}{$\begin{array}{l}56.3 \% \\
(9 / 16)\end{array}$} \\
\hline & & 放 $\rightarrow$ 全摘 & 1 & 0 & 0 & 0 & 0 & 0 & \\
\hline & & 全摘 & 17 & 2 & 2 & 5 & 0 & 2 & \\
\hline \multirow{3}{*}{ IV } & \multirow{3}{*}{11} & 部切 & 1 & 1 & 1 & 0 & 1 & 0 & \multirow{3}{*}{$\begin{array}{l}62.5 \% \\
(5 / 8)\end{array}$} \\
\hline & & 放 $\rightarrow$ 全摘 & 1 & 0 & 0 & 1 & 0 & 0 & \\
\hline & & 全摘 & 9 & 0 & 0 & 1 & 1 & 1 & \\
\hline
\end{tabular}

切は 2 例とあ良好であった。

2. 部位別病期別治療成績および予後

1）声門癌

声門癌79例の Stage 分類および症例数, 治 療法，予後を表 5 に示した。 Stage I は23例， II 24例, III 21例, IV11例で, 比較的早期の症例が 多くみられた。遠隔転移例はなかった。初診時 頸部リンパ節転移のみられた例は16例 (20.3\%) であった。声門癌全体の 5 年確定生存率は 70.5 \%であった。

\section{i) Stage I}

Stage I は23例あり，そのうち18例が放射線 照射例である．照射例のうち，局所再発例は 2 例にみられ， 1 年半後と 4 年半後に全摘を行い 生存中である。また $70 \mathrm{~Gy}$ 照射の 1 例で照射 後, 喉頭壊死による出血で喉頭全摘を余儀なく された例がある。

手術例は全部で 5 例で, 部切が 4 例, 全摘が 1例ある。いずれも予後は良好である. Stage I の腫瘍死は, 放射線治療例の 1 例のみであっ た. Stage I の 5 年確定生存率は $82.4 \%$ あっっ た.

\section{ii) Stage II}

Stage II は24例ある。そのうち放射線㙩法が 7 例, 部切 2 例, 残り 15 例は全摘を行ってい
る，放射線照射例には，肺転移例が 1 例含まれ るが，その例之，原発巣コントロールのできな かった例の 2 例が腫瘍死している，部切を行っ た 2 例は，いずれも予後良好である．全摘例で は，頸部再発例が 3 例みられ，このうちの 1 例 之，気管孔再発の 1 例および全身転移例の 3 例 が死亡している. Stage II の 5 年確定生存率は 78.9\%であった。

\section{iii) Stage III}

Stage III の21例のうち，放射線照射例は 4 例 ある。 4 例中 1 例で, $40 \mathrm{~Gy}$ 照射後も腫瘍が残 存したため全摘を追加し，現在生:存中である。 全摘を行ったのは17例で，乙のうち 2 例に局所 再発がみられた。 $\mathrm{T}_{3}$ 症例で，緊急気管切開後， 全摘を行った例が 1 例あるが，幸いにして，乙 の例の予後は良好であった。局所再発例および 肺転移例の 5 例が腫場死している. Stage III の 5 年確定生:存率は $56.3 \%$ あっあた。

\section{iv) Stage IV}

Stage IVは全部で11例ある，1例に照射後全 摘を行っているが, 腫瘍死している。 $\mathrm{T}_{1} \mathrm{~N}_{2} \mathrm{M}_{0}$ の 1 例で部切を行った例では， 5 力月後に全 摘，頸部郭清術を追玑したが脳溢血で死亡して いる。全摘を行った例は 9 例であった。 5 年碓 定生:存率は $62.5 \%$ であった。 
表 6 声鬥上癌の原発坚治療および予後

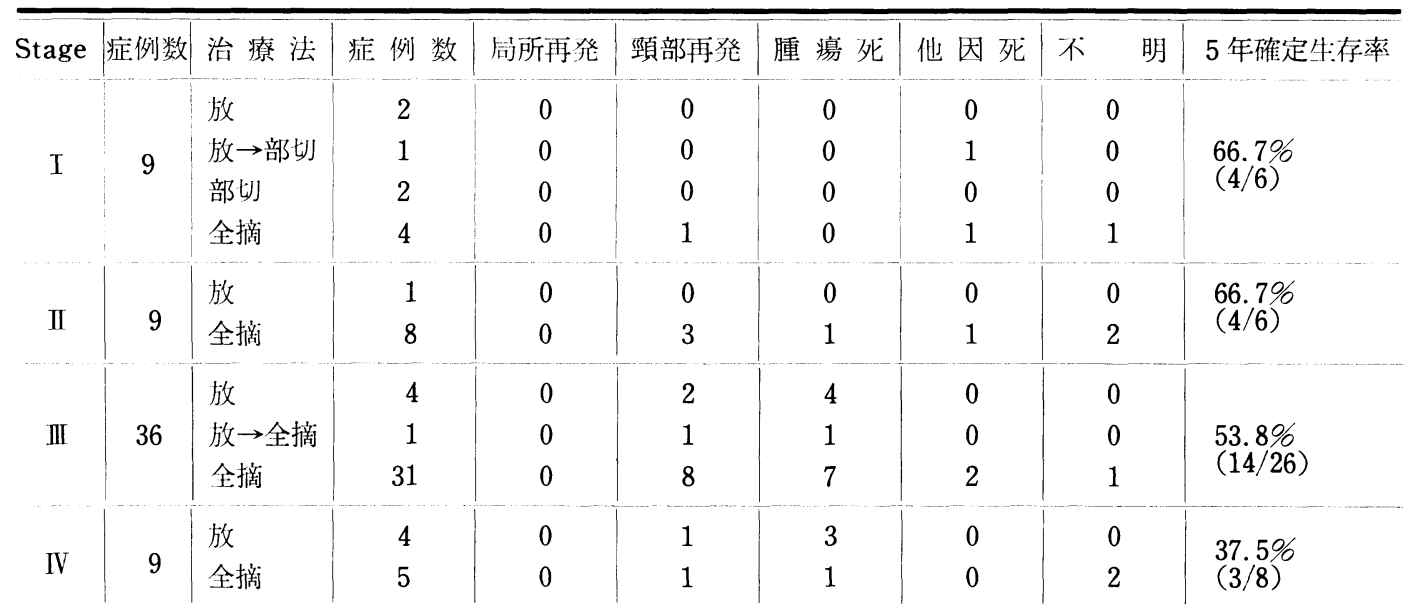

2）声門上嵒

吉門上癌63例の Stage 分類および症例数, 治療法, 予後を表 6 に示した. Stage I は 9 例, II 9 例，III36例，IV 9 例で，初診時すでにかな り進行した例が大半を边ている。初診時, 頸 部リンパ節転移のみられた例は23例（36.5\%） で，声門癌より多かった。声师上嵒全体の5年 確定生存率は54.3\%であった。

\section{i) Stage $I$}

Stage I は9 例あるが， 3 例に放射線療法を 行っている。そのうち 1 例は 60Gy 照射後, 唯 頭室に腫陽の残存を認め，半側切除を行い，再 発を認めなかったが， 3 年後に心矨梗寒で死し した。部切例は 2 例あるが，いずれも予後埕奵 である。全摘は 4 例で， 1 例に頸部郭清術，リ ンパ節摘出を追川している。 5 作確定生:存率は 66.7\%であった。

\section{ii) Stage II}

Stage II は 9 例ある。1 例に放射線䝤法を行 い生存中である。残り 8 例は全摘症例である。 䋂過け， 3 例に頸部リンパ節転移を生じ，頸部 郭清術を追玑したが，1例で更に肺に転移し た。 5 年確定生存率は，66.7\%であった。

\section{iii) Stage III}

Stage III は36例ある。 5 例に放射線療法を行 っているが，そのうちの1例に全摘を追加して
いる。しかし，この例も含め，照射例は全例腫 陽死している。全摘を行ったのは31例である。 1 例で，緊急気管切開後に全摘を行った例があ るが，腫瘍は声門下゙まで到っており不幸な転帰 をたどっている，頸部郭清術を行ったのは $\mathrm{N}_{1}$ 症例のうちの11例であるが， 3 例に頸部再発が みられた。 5 年確定生:存率は53.8\%であった。

iv) Stage IV

Stage IVは 9 例ある。心疾患や，患者の強い 希望などの理由で 4 例に放射線療法を施行し, 吏に 2 例には頸部への照射も併用しているが 3 例が死ししている。全摘は 5 例に行われ，1例 で頸部再発がみられた。 5 年確定生:存率は37.5 \%と不餀である。

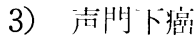

声鬥下嵒 9 例の Stage 分類および症例数, 治䝤法，予後を表 7 に示した. Stage I 1 例, II 5 例， III 2 例，IV 1 例であった。初診時頸部 リンパ節転移が 2 例にみられた。

Stage I，II の3 例に放射線療法を行ってい るが，1例は腫陽死，2例に全摘を追加してい る. Stage II では，化学療法のみの治療しか行 えなかった例が 1 例あるが，死ししている。 Stage III，IVはいずれ屯全摘を行っている。声 鹏下癌全体の5 年確定生:存率は50\%であった。

3. 頸部リンパ節転移について 
表 7 声門下癌の原発巣治療および予後

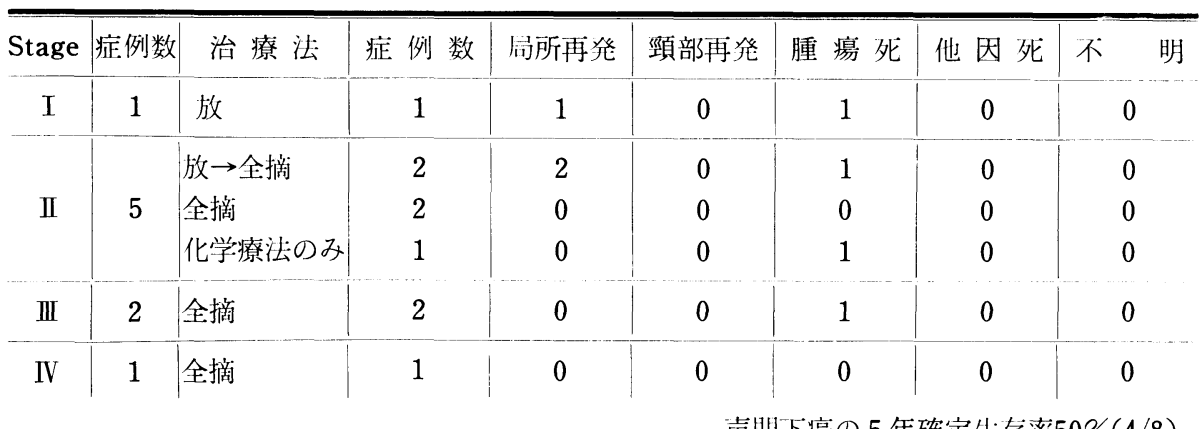

声閏下癌の 5 年確定生:存率 $50 \%(4 / 8)$

表 8 钼部リンパ節転移の治療および転帰

\begin{tabular}{|c|c|c|c|c|c|c|c|}
\hline & 治療方法 & 症 例 数 & |リンパ節再発 $\mid$ & 腫 瘍 死 & 他 因死 & 不 & 明 \\
\hline \multirow[t]{2}{*}{ N 1} & 頸郭 & 14 & 3 & 3 & 1 & 2 & 2 \\
\hline & 放 & 2 & 2 & 2 & 0 & ( & 0 \\
\hline \multirow[t]{2}{*}{ N 2} & 頸郭 & 1 & 1 & 1 & 0 & ( & 0 \\
\hline & リン摘 & 2 & 0 & 1 & 0 & c & 0 \\
\hline \multirow[t]{3}{*}{ N 3} & 頸郭 & 3 & 0 & 0 & 1 & 2 & 2 \\
\hline & リン摘 & 1 & 0 & 0 & 0 & 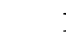 & 1 \\
\hline & 放 & 2 & 0 & 1 & 0 & ( & 0 \\
\hline
\end{tabular}

表 9 初診時 $\mathrm{N}_{0}$ で経過中頸部リンパ節転移を少:じた例および転州

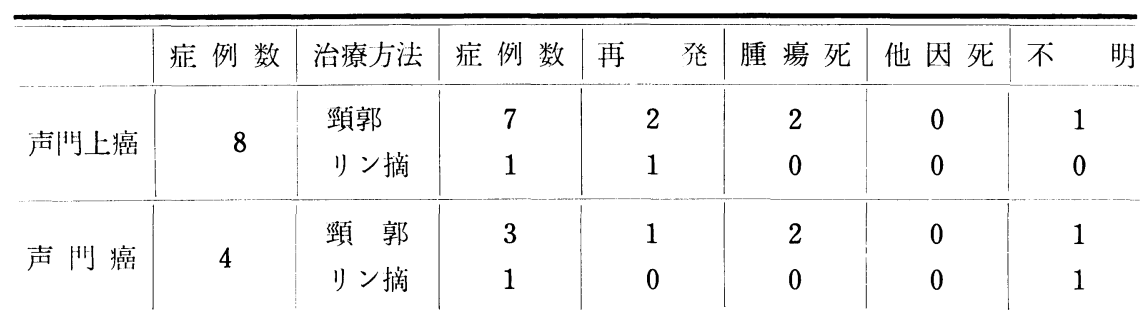

初診時，頸部リンパ節転移のみられた例の一 次治療後の転帰を表 8 に示した。 $\mathrm{N}_{1}$ 症例では 14例に頸部郭清術を行ったが, 声門上癌の 3 例 に再発がみられた。そのうちの 2 例を含めて 3 例が腫愓死している。頸部に放射線照射を行っ た 2 例は，いずれも再発し死亡している。 $\mathrm{N}_{2}$ 症例では頸部郭清術例が 1 例あるが腫隍死して いる。 $\mathrm{N}_{3}$ 症例では，放射線照射を行った例が 2 例あり，1例が死ししている。頸部郭清術例 は 3 例あるが，他肉死 1 例，不明 2 例であっ
た。

初診時 $\mathrm{N}_{0}$ で，経過中頸部りンパ節転移を生: じた例は，声門上癌 8 例 $\left(\mathrm{N}_{0} 40\right.$ 例中 $\left.20 \%\right)$, 声 門癌 4 例（No63例小6\%）にみられた（表 9$)$. 8 例で頸部郭清術， 2 例にリンパ節摘出術を施 行したが，声門上嵒の 3 例に更に再発がみられ た。

経過川頸部リンパ節転移をきたした例も念め ると，37例の頸部リンパ领転移川15例 (40.5\%) がコントロールできたことになる。 
考

1. 対像症例について

喉頭癌症例の年柃については，60歳台に最む 多く,50歳台が続き，70歳台以上の高歯者にも $23 \%$ とかなりの患者数がみられた。佐藤 ${ }^{1)}$ は 1950年までは, 喉頭癌は50歳台に最も多くみら れたが，1950年以降は，ピークが60歳台に移行 したとしており高阾化の傾们がうかがわれる。 性别では，男性に厈倒的に多くみられ，父性 はわずか $3.3 \%$ あったた。他の報告23)45)でも 文性の頻度は7-10\%であった。

部位別では，声門癌が最も多く $52.3 \%$ \% ‘ め, 次いで声門上癌は $41.7 \%$ あった。この成 績は壮野ら 320 報告とほぼ同様であるが, 草刈 $ら^{4)}$ ，玉出ら5)，鈴木ら ${ }^{6)}$ の報告に比べると声門 乚癌の比率が大きかった。文性喉頭癌症例は, 卢門上癌 3 例, 声門癌が 2 例であった。

Stage 分類では, 声門癌が Stage I から III まで大着なく分布しているのに対し，声門上嵒 は Stage IIIが58\%と6㓶近くを沙め, Stage III, IVを合わせると, 声門.上嵒の71\%となり, 声門癌の Stage III, IV の比率が40\%であるの と比べて，はるかに進行嵒が多くみられた。こ の愿因としては, 声师上癌の片が, 声門猛より 屯所覚症状の発現が遅れることや，従来から指 摘された様(3)に，声門上癌では初診時，かな りの症例に頸部リンパ節転移例のみられること などが考えられる。

2. 治療成績について

今间の治療成績については, 5 年確定生:存率 で算出したため, 従来の報告との単純な比較は 林難な点もある。知頭癌全体の 5 年確定生存率 は62.6\%であったが，嘢ら3007\%（5 年粗 生存率), 鈴木ら ${ }^{6)}$ の $66 \%$ ( 5 年粗生存率) と 比較して，それほどの着はみられない。声門癌 では，当科では70.5\%であったが，壮野ら3は $79 \%$ ( 5 年実生:存率), 琵出ら 5 は $66.2 \%$ (5 年䇣積生存率）としている。声門上癌は当科で は54.3\%であったが，斗野ら3）は65\%（5年実
按

生存率)，玉虫ら ${ }^{5)} 59.4 \%$ (5 年累積生存率) また声門下癌は当科では50\%で， 雨野ら ${ }^{3)} 50$ \%（5 年実生:存率）となっていた。概权，その 治療成績は他の報告と，さほど大きな差はない ようである。

\section{3. 原発巣の治療について}

1）治療方法について

治療法では，全摘が最屯多く62.9\%を占め，

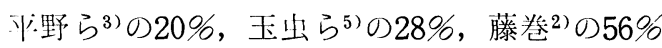
草刈ら4055\%と比へても多かった。 この原闪 としては，乙れらの報告と此べて，当教室の例 では声門上癌が多く，特にその川でも進行癌が 多くみられたことがあげられる。また放射線療 法, 部切の邀応が比較的厳しく, 懸念のある症 例は全摘が行われる傾问にあったとと屯考えら れる。 5 年確定生存率は, 全摘の方が, 放射線 療法よりも上まわっていた。部切は 5 年確定生: 存率 $100 \%$ と良好であった。放射線療法の予後 を部位別にみると, 声門癌の 5 年確定生存率が 72\%であるのに対し，声門上癌では33\%と不良 であった。これは声門上癌では, 症例が初期か ら進行癌までにわたっていたためと思われる。

2) 声門癌

声門癌では，放射線療法のトめる割合が高 い. Stage I では放射線療法が $80 \%$ を占め, 比 較的良い成績をあげている。局所再発例の 2 例 屯手術によってコントロールされており, 予後 は良い. 部切例も含めて, Stage I では95\%以 上に機能保存的治療が行われていた。

Stage II では, 放射線照射例は30\%で，他施 設の報告と比べ3(5)6), 全摘の占める比率が大き いのが特徵といえる。即ち, 放射線療法, 部切 の邀応が览格であるといえる。そのため射照例 の局所再発例はなく, 部切之もども良い成績を あげている，放射線療法の噈応について佐藤》 は，㵅陽，依死，浮腫など血行障皆のあるもの は放射線に抵抗を示すとし，また $\mathrm{T}_{2}$ ひ声門下 腔に進展している例や，前連合に潰陽のあるも 
のは，放射線療法の非適応とのべている，こて では Stage II の半数以上で全摘が施行されて いたが，てのうち死ししたのは，全身転移例と 手術扑否例のみで, 治療成績は良好である。し かし, 今後機能保存の治療の努力が更に必要で あると思われる。

Stage III，IVの中には手術扰否などの理由で 根治照射を行い, 治癒の得られた例もあるが, 主体は喉頭全摘である。 Stage III, IVでは，喉 頭癌といえども, 全摘例の 5 年生存者は半数以 下に減ってしまい，機能保存むさることなが ら，まず確実な治療が必要である，術前照射之 全摘の組み合わせが 2 例あるが，乙れについて 山本ら委は, Stage III 以上の症例では手術単独 より照射併用の方がすぐれているとし，一方藤 卷2)は, 手術的療法のみの方が, 照射併用群よ りも 5 年生存率は高いと報告している。今回の 観察では併用群は 2 例のみで, 明確な結論はひ きだせなかった。また, Stage III の生存率は,

Stage IVよりむしろ曹くなっていたが，ての一 因として, 小野ての指摘した如く, $\mathrm{T}_{3}$ 之診断さ れた例の中には, みかけよりも深部進展の著し い例が含まれた可能性があり，化学療法や免疫 療法などの組み合わせも必要之思われた。

3）声門上癌

声門上癌の Stage I は, 放射線療法, 部切, 全摘之治療法が分かれている。いずれも治療成 績は良好であった． Stage II 以上は，手術療法 が主体であり，局所再発例はなかった。声閒上 癌の場合, 佐藤 ${ }^{1}$, 藤卷 ${ }^{2}$ らの指摘のように,
頸部リンパ節のコントロールの邚何が, 南接予 後を左右するものといえよう。

4. 頸部リンパ節転移の治療について

今回の観察では, 喉頭癌症例の $27 \%$ に, 初診 時頸部リンパ節転移を認め, 経過川に転移を生: じた例も含めると約 $35 \%$ に認めた。頸部リンパ 節の部位別頻度は，声門_上癌 $49 \%$ ，声門癌 $26 \%$ で，他の報告1)2) と比べると，声門上癌は同程 度であるが，声㱚癌では幾分多くみられた。

頸部リンパ節転移の治療には, 放射線照射, リンパ節摘出術, 全頸部郭清術が行われていた。 放射線照射のみでは，照射例の 2 例之屯死亡し て抢り，草刈4)，玉虫ら50報告をみて屯，良好 な結果は殆ど期待できないといってよい。やは り, 頸部郭清術を徹底して行うべきであろう。

広戸9'は, 予防的頸部郭清術について, 特に 声門上癌, 川であ Epilarynx に腫瘍のある例 については, 初回治療時に行うべきとのべてい る。これに対し，われわれは，経過観察中，䍀 㦿的に頸部リンパ節転移が疑われた時点で, 頸 部郭清術を行ってきた。それによってコントロ 一ルされた例もあるが, 時に経過観察の不十分 な症例があり，頸部リンパ節転移による腫瘍死 が多くみられた一肉ともなっている. Bagshaw ${ }^{10)}$, Simonetta ${ }^{11)}$, 草划) らは $\mathrm{N}_{0}$ のものに予(防j 的に頸部に照射を行い，施行しなかった群に比 べて有意の差があり，平野ら ${ }^{3)}$ の予防的頸部郭 清術後の転移出現率とも大养なかったと報告し ている，今後，症例によっては，試みてよい方 法ではないかと思われる。

語

1）過去14年間に当科で加療を行った聅頭癌151例について, 統計的観察を行った。

2）倠頭癌全体の 5 年確定生存率は62.6\%であった。声門癌の 5 年確定生存率は $70.5 \%$ Stage I は82.4\%，II 78.9\%，III 56.3\%，IV62.5\%であった。声門上癌の 5 年確定生存率は $54.3 \%$, Stage I は66.7\%, II 66.7\%, III 53.8\%, IV 37.5\%であった。声門下癌の 5 年生存率は $50 \%$ あったた。

3）堠頭癌の治療成績の向上のためには, 原発巣とともに, 頸部リンパ節転移に対するコントロー ルが重要であると考えられた。

本論文の要旨は第33回東北連合学会で発表した. 


\section{参考 文 献}

1）佐藤武男：喉頭癌，その其礎之臨冰，金原州版， 東京, 1972 .

2）藤卷竜枝：喉頭癌の儖木統計的観察。11耳鼻 76 : 533 577, 1973.

3）米野 実，他：教室における喉頭癌の遠隔成紹。 耳鼻 $22: 748 \sim 759,1976$.

4）草刈 潤，他：喉頭癌の治療成績について。耳鼻 $25: 305 \sim 312,1979$.

5）玉虫 算, 他：当教室における10年闑の喉頭癌治 療について。耳鼻 $29: 828 \sim 833,1983$.

6）鈴木炤男，他：喉頭癌の臨㦿統計似観察。耳鼻臨 休 $76: 1105 \sim 1115,1983$.

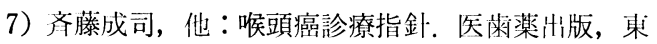
京, 1981.

8）山本昭郎，他：喉頭癌の治療成績。山矤放：940 $\sim 949,1978$.

9）広戸幾一郎：頭頸部領域の癌に対する昖大根治下: 術。癌の臨休 $21 ： 1123 \sim 1129,1975$.

10) Bagshaw MA, et al : Elective irradiation of the neck in patients with primary carcinoma of the head and neck. JAMA $217: 456 \sim 458$, 1971.

11) Simonetta B, et al : Total laryngectomy followed by radio therapy instead of "prophylactic" neck dissection. Arch Otolaryngol 76 : 451 456, 1962.

別刷請求先：佐滕洋子.

T960 福島市杉妻町 $4-45$

福島県立医科大学耳鼻咽喉科学教室) 